\title{
THE EFFECT TRANSFORMATIONAL LEADERSHIP, PERSONALITY AND JOB PERFORMANCE ADMINISTRATION EMPLOYEE
}

\author{
Andinasari*, Bedjo Sujanto**, Mukhneri Mukhtar*** \\ Indonesian United Teachers University of Palembang \\ State University of Jakarta \\ State University of Jakarta \\ Andinasariunippgri@gmail.com \\ bedjosujanto@unj.ac.id \\ mukhnerimukhtar@unj.ac.id
}

\begin{abstract}
The purpose of this study was determine the effect transformational leadership, personality and job performance administration employee University of Indonesian Teachers Union of Palembang (PGRI). This research try answer problems about job performance involving of 144 administration employee had been selected from the target population of 223 employee by using quantitative approach with path analysis methods. The reseach of conclude show (1) transformational leadership had a direct effect positif on job performance; (2) Personality had a direct effect positif. Therefore to improve the job performance administration employee PGRI University of Palembang.
\end{abstract}

Keywords: Transformational Leadership, Personality, Job Performance.

In the current era of globalization is characterized by increasingly fierce competition, it is necessary to have quality human resources so as to be able to face competition and change. The quality of human resources is currently the main focus of various studies in the field of organizational management because human resources are the factors that distinguish between developing countries from undeveloped countries. Therefore, improving the quality of human resources as the actors of development makes the role of education to be very strategic. This is based on educational objectives, among others, to establish quality human beings.Efforts to improve the quality of human resources as a perpetrator of development, is determined by the quality of education. Especially PGRI University of Palembang is one of the educational institutions that prepare human resources in the field of education and non-education. To prepare qualified human resources, it needs a process of academic and administrative services of quality as well. On the contrary, the process of unprofessional academic and administrative services will hinder the achievement of organizational goals. The level of administrative services of an organization is a description of the high level of performance of administrative staff of the institution concerned.

The level of performance of administrative staff can be seen from the attendance at the workplace caused by the lack of employee discipline and the ineffective and inefficient use of time in carrying out the work are phenomena that are often found in public service organizations. Performance can also be caused by technical aspects in a culture or work system that are less supportive, such as unclear tasks and functions of an employee, high workload (can be caused by lack of employees, high work volume, etc. ).

The success of a college as an organization can be measured by the level of performance, both organizational performance and individual performance of administrative staff who can work effectively and efficiently in supporting and facilitating the implementation of the tasks of teaching staff or lecturers, as well as the performance of lecturers as a superior and productive teachers in the field of teaching, research, and community service. In addition, there is still a tendency of employees who only prioritize attendance records, but for the real reason only to get a reward incentive presence. On the other hand there is also an inclination of employees to always go home on time, they sometimes deliberately delay or leave their current job just to get home on time. Such things if left will result in a work culture that is lazy and oriented toward rewards, sluggish and not creative, and less productive among administrative clerks.

In the implementation of the main tasks and functions that have not been maximized is also a measure that the performance of administrative personnel PGRI University of Palembang is still not maximized. In addition, based on the 2016 annual report of the personnel department in the management of 
attendance of administrative personnel, either manually or on line or system (finger print), the overall recap of attendance can not be processed. In accordance with the rules of an employee will get an oral reprimand if not entered without news for 3 days, and then if do not enter again without news will get written warning from head. As for the absence on a daily basis for no valid reason there will be a cut of transport money. Administrative staff whose total absence exceeds the limit will there be sanctions until the demotion.

Based on data on the Annual Report of Universitas PGRI Palembang Year 2016, the percentage of attendance of administrative staff in accordance with working hours and schedule of activities around 70\% can only be realized by $92 \%$. Based on attendance recap data obtained from each work unit for the calculation of food allowances per month, by 2016 there are still administrative employees who are absent without news beyond the tolerance limit or even should get a reprimand and punishment from their immediate supervisor. Judging from the number of employees who are not present is not much, at least 1 or 2 people, but it if left unchecked will affect other administrative staff or become a habit that will spread to other employees. If this is left continuously it will degrade the authority of the leader and lead to a decline in overall performance.

Based on the results of the quality guarantees evaluation in the 2016 annual report, as for why there are still indicators indicating the low performance of administrative staff, among others, can be caused by the presence of other colleagues are also lazy. In fact there are also their direct tops who are also lazy, slow and not creative. In other cases there is also an argument that it has not understood the organizational structure and governance and the main tasks and functions of each unit of work and employees in it, and not assertive direct supervisor in enforcing discipline. Therefore, the leadership role of an employee's direct superior is very important in encouraging and motivating, and inspiring, so that employees can demonstrate their commitment, work diligently, focus, work well in their team or in their work unit, feel the same destiny and with their colleagues others, and have a sense of pride and a sense of belonging to the existence of the University, so it is responsible.

Rivai (2005: 49) Performance of employees can be improved if employees know what is expected of them, when they are allowed to participate in the process of stabilizing these expectations and when they are assessed from the results. There are two factors affecting employee performance that is external factors and internal factors. External factors are factors that outside the self-employee such facilities provided by the company or a comfortable working environment. Internal factors are coming from within the individual employees such as personality, abilities and attitudes that have someone to contribute to employees in achieving good performance.

A person's personality is a collection of relatively stable features and temperaments influenced by social, cultural, and environmental factors. Some aspects of personality that affect one's behavior are the determinants of personality (heredity, environment, and situation), and personality traits such as caution, stability and emotionality, and openness to experience.

The personality of each individual is not the same as the other individual and can not be changed easily according to the will of others or someone. If the personality of an individual in an organization is changed then it will be able to reduce the motivation in work and achievement. Leaders should not seek to change a person's personality so that it forces them to adapt their personality to the ideal model of the person they are, but must try to overcome the various personalities of the employees they lead.

Regarding performance, Colquitt, et.al., states: "Job performance is formally defined as the value of the set of employee behaviors that contribute, either positively or negatively, to organizational goal accomplishment. Colquitt explains formal performance is a set of judgments that contribute to positive and negative employee behavior, for organizational purposes. Indivudu performance will be part of the performance of employees in terms of quality also in terms of quantity based on predefined working standards.

Leslie W. Rue, and Lloyd L Byars (... ..) define performance as follows: "job performance is the net of an employee's effort as modified by abilities and role (or task) perceptions. Thus, performance in a given situation can be viewed as resulting from the inter-relationship ". Performance is an effort made by an 
employee associated with the ability and role or perception of the task. So performance is the work achieved by an employee in performing its functions in accordance with the responsibilities given to it

According to Gary Yulk (... ..): With transformational leadership, the followers fell trust, admiration, loyalty and respect to the leader and they are motivated to do more than they originally expected to do. the leader transforms and motivates them to transcend their own interests.

With transformational leadership, followers trust, admire, loyalty and respect for leaders and they are motivated to do more than they do early on. Leaders transform and motivate followers that administrative staff are more aware of the importance of task results, encouraging them to transcend their self-interest for the sake of the organization or team and activate high needs.

While Gibson et.al., defines transformational leadership that, "transformational leadership is the ability to inspire and motivate followers to achieve greater results than those planned for internal prizes.

According to Buchanan and Huczynskibahwa the concept of personality is a basic psychological identity or a unique character used to measure and understand the differences between individuals with one another. So it can be concluded that what is meant by the personality is how strong the psychological can affect the pattern of behavior or individual nature continuously and typical when compared with other individuals.

Specifically Rivai, explains the factors that determine personality: (1) heredity, heredity refers to the factors that are determined at the time of change. Physical characteristics, facial attractiveness, tempramen, muscle composition and reflexes, energy levels are characteristics generally regarded as or at all or largely influenced by the attitudes of both parents, (2) the environment. It shows that affect the impact of offspring and the environment on the personality. Theoretically, the linkage of transformational leadership with performance is explained by Colquitt, Lepine, Wesson (2013: 483) Transformational leadership has a moderate positive effect on performance. Employees with transformational leaders tend to have higher levels of task performance. They are also likely to engange in citizenship behavior. Less is known about the effect of transformational leadership on counterproductive behavior. That transformational leadership has a moderate impact on work performance. Administrative employees with transformational leadership tend to have higher performance. The personality of an Administration Officer in an organization becomes very important. If an Administrative Officer has an appropriate personality in the field of work then within him will encourage increased work productivity.

\section{METHOD}

This research was conducted with the aim of: 1. Knowing the positive direct effect of transformational leadership on the performance of administrative personnel of Universitas PGRI Palembang, 2.Mengetahui direct positive influence of personality on the performance of administrative staff of University PGRI Palembang.

The research was conducted at PGRI University of Palembang, South Sumatera Province, conducted in February - May 2017, using quantitative approach through survey method using path analysis technique. Using SPSS Version 22 program help. This research consists of three independent variables. Including transformational leadership (X1), personality (X2) one dependent variable is employee performance (Y).

Target population in this study is the Administrative Staff of PGRI University of Palembang, while the population is the PGRI Palembang Administration Administrator numbered 223 people. Because the population of administrative staff of Universitas PGRI Palembang consists of several units of work, the sample is also taken proportionally random sampling according to the number of administrative employees in each work unit.

Technique of collecting data is done by using research instrument in the form of questionnaire. This research consists of 3 (three) kinds, each instrument on (1) transformational leadership, (2) personality, and (3) employee performance using Likert scale model. Likert scale with 5 (five) alternative answers, strongly agree, agree, hesitate, disagree and strongly disagree. For Performance (Y) variables, transformational leadership (X1), questionnaire techniques with 5 alternative answers. that is always, often, sometimes, rarely, and never. Alternative answers are assigned a weight value of 5 to 1. 
Data Analysis Technique using inferential analysis is used to test the research hypothesis using path analysis as comparison. All hypothesis testing using $\alpha=0.05$. Before the hypothesis test is done first tested the normality of regression estimate error by using Lilifors technique and significance test and linearity test. The tool used for this analysis is SPSS V. 22 Program.

\section{RESULTS}

This data is obtained after the research instrument is given to the research sample of administrative staff at the University PGRI Palembang as many as 144 people. Further data is processed by using descriptive statistical techniques. Description of data about research variables are transformational leadership variable (X1), personality (X2), achievement motivation (X3) and employee performance (Y) and complete recapitulation of research data are presented in table 1 below.

Table 1. Recapitulation Description of Research Data

\begin{tabular}{|l|l|l|l|}
\hline Value Statistics & $\begin{array}{l}\text { Transformational Leadership } \\
(\mathrm{X} 1)\end{array}$ & Personality (X2) & $\begin{array}{l}\text { Employee } \\
\text { Performance (Y) }\end{array}$ \\
\hline $\mathrm{N}$ & 144 & 144 & 144 \\
\hline Mean & 113,09 & 101,24 & 105,33 \\
\hline Median & 114,00 & 102,00 & 106,50 \\
\hline Mode & 113,00 & 104,00 & 108,00 \\
\hline Std Deviation & 4,791 & 4,875 & 5,709 \\
\hline Variance & 22,950 & 23,762 & 32,587 \\
\hline Maximum & 124 & 87 & 116 \\
\hline Minimum & 97 & 114 & 86 \\
\hline Range & 27 & 27 & 30 \\
\hline
\end{tabular}

Path analysis, data must meet some statistical test requirements, namely: (1) Normality Test, (2) Regression Linearity Test and (3) Significance Test of Regression Coefficient.

The test criterion is if Lo $<\mathrm{L}$ table with $\alpha=0.05$ then Ho is accepted which means the random error is normally distributed. From the result of random error test of regression model from transformational leadership variable to employee employee performance variable, based on result of calculation analysis attached obtained value Lhitung $=0,0623$, while $L$ table value (critical value of Liliefors) at $\alpha=0,05$ and $n=$ 144 , is 0.0738 . From the results it is known that the value of Lhitung $=0,0623<$ Ltabel $=0,0738$, so Ho accepted. It can be concluded that the random error of the transformational leadership variable regression model on the performance of the employee is derived from the normal distributed population.

From the results of the normality random error test of the performance of employees, based on the results of the calculation analysis attached value obtained Lhitung $=0.0725$, while the value of $\mathrm{L}$ table (Liliefors critical value) at $\alpha=0.05$ and $n=144$ is 0.0738 . From the results it is known that the value of Lhitung $=0,0725<$ Ltabel $=0,0738$, so Ho accepted. It can be concluded that the random error of regression model of variable keperibadian to employee performance of employees comes from normal distributed population. Thus it can be concluded that the distribution of selected data in all groups comes from a normally distributed population. The results of Liliefors test calculation can be seen in table 2 below:

Table 2. Summary of Normality Test Result

\begin{tabular}{|l|l|l|l|l|}
\hline Random Error & Value Lo & \multirow{2}{*}{ Valuei L table } & Description & Conclusion \\
\hline $\mathrm{X}_{1}$ to $\mathrm{Y}$ & 0,0623 & \multirow{2}{*}{0,0738} & $\mathrm{~L}_{\mathrm{o}}<\mathrm{L}_{\text {table }}$ & Normal \\
\cline { 5 - 5 } $\mathrm{X}_{2}$ to $\mathrm{Y}$ & 0,0725 & & $\mathrm{~L}_{0}<\mathrm{L}_{\text {table }}$ & Normal \\
\hline
\end{tabular}

Based on the calculation of regression equation model between transformational leadership variables (X1) to employee performance variable $(\mathrm{Y})$ obtained regression equation $\mathrm{Y}=-9,371+1,014 \mathrm{X} 1$. 
Based on the results in table 4.7 above, for the test linearity obtained value Fcount $=1.368$, while Ftable on $\alpha=0.01$ of 1.9528 and at $\alpha=0.05$ of 1.6099 . Because Fcount $<$ Ftabel, then Ho is accepted thus there is a linear relationship between $\mathrm{X} 1$ and $\mathrm{Y}$, so that the regression model of influence of transformational leadership variable (X1) on employee employee performance variable (Y) can be inferred linearly.

Furthermore, in testing the significance of regression model $\mathrm{X} 1$ to $\mathrm{Y}$ in table 4.7 above produces the value Fcount $=373,429$, while Ftable on $\alpha=0.01$ of 6.8168 and at $\alpha=0.05$ of 3.9078. Since Fcount $>$ Ftable, then Ho is rejected. Thus the regression coefficient of variable $\mathrm{X} 1$ to variable $\mathrm{Y}$ is significant or significant so it can be concluded that transformational leadership variable (X1) significant effect on employee performance variable $(\mathrm{Y})$. Based on the result of calculation model of regression equation between personality variable $(\mathrm{X} 2)$ to employee performance variable $(\mathrm{Y})$ obtained regression equation $\mathrm{Y}=2,795$ $+1,013$ X2 for linearity test obtained value Fhitung $=1,112$, while Ftabel at $\alpha=0,01$ equal 1, 9891 and at $\alpha=$ 0.05 of 1.6317. Because Fcount <Ftable, then Ho is accepted thus there is a linear relationship between X2 and $\mathrm{Y}$, so that the regression model of the influence of personality variable (X2) on employee employee performance variable $(\mathrm{Y})$ can be inferred linearly.Furthermore, on testing the significance of regression model $\mathrm{X} 2$ to $\mathrm{Y}$ in table 4.8 above yield value Fcount $=421,609$, while Ftable at $\alpha=0.01$ equal to 6,8168 and at $\alpha=0,05$ equal to 3,9078. Since Fcount $>$ Ftable, then Ho is rejected. Thus the coefficient of variable X2 regression to variable $\mathrm{Y}$ is significant or significant so it can be concluded that the personality variable (X2) significant effect on employee performance variable (Y).

Based on the calculation results, it can be presented summary of linearity test results and significance of regression equation of the relationship of variables $\mathrm{X} 1, \mathrm{X} 2$, and $\mathrm{Y}$ as follows:

Table 3. Summary of Linearity Test Results For All Variable Relationships

\begin{tabular}{|l|l|l|l|l|l|}
\hline Relationship & Pers. Regression & $\mathrm{F}_{\text {Count }}$ & \multicolumn{2}{|l|}{$\mathrm{F}_{\text {table }}$} & \multirow{2}{*}{ Conclusion } \\
\cline { 4 - 6 } & & & $\alpha=0,05$ & $\alpha=0,01$ & \\
\hline $\mathrm{Y}$ and $\mathrm{X}_{1}$ & $\hat{Y}=-9,371+1,014 \mathrm{X}_{1}$ & 1,368 & 1,6099 & 1,9528 & Linier \\
\hline $\mathrm{Y}$ and $\mathrm{X}_{2}$ & $\hat{Y}=2,795+1,013 \mathrm{X}_{2}$ & 1,112 & 1,6317 & 1,9891 & Linier \\
\hline
\end{tabular}

The result of the first structural model estimate is further presented in the following figure.

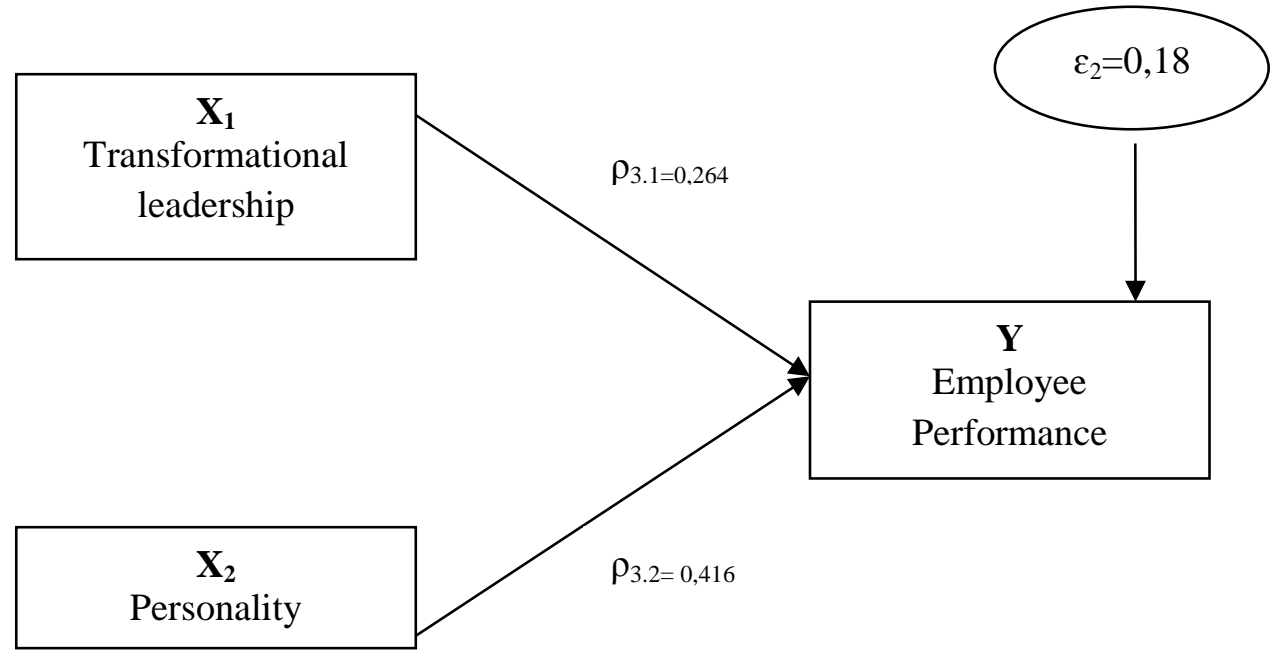

Figure 1. Structural path diagram

From result of hypothesis testing obtained by coefficient value of path ( $\rho Y .1)$ equal to 0,264 ( $\rho Y .1>$ 0 ) with tcount 2,324 and sig value. (p-value) $=0.022 / 2=0.011$. Whereas for $\mathrm{dk}=142$ at $\alpha=0,05$ obtained ttable $=1.977$ and at $\alpha=0,01$ obtained ttable $=2,611$, so tcount value $>$ ttable and sig value. $<\alpha$, thus Ho is rejected. This means that it can be concluded that the transformational leadership variable (X1) has a direct positive effect on employee performance (Y). 
Personality (X2) has a direct positive effect on Employee Performance (Y) Hypothesis test to prove that personality (X2) have a direct positive effect on employee performance (Y), From the calculation result obtained coefficient point $(\rho Y .2)$ of $=0,416(\rho Y .2>0)$ with tcount of 3.477 and the sig value. $(p$-value $)=$ $0.001 / 2=0.0005$. Whereas for $\mathrm{dk}=142$ at $\alpha=0,05$ obtained ttable $=1.977$ and at $\alpha=0,01$ obtained ttable $=2,611$, so tcount $>$ ttable or sig value. $<\alpha$ thus Ho is rejected. This means that it can be concluded that the variable keperibadian (X2) directly positive effect on employee performance (Y). Based on the results of previous hypothesis testing, the summary test results of each hypothesis is presented in table 4 below:

Table 4. Summary of Hypothesis Testing Results

\begin{tabular}{|l|l|l|l|l|l|l|}
\hline Path & Path Coefficient & $\mathrm{t}_{\text {Count }}$ & Sig. & $\begin{array}{l}\mathrm{t}_{\text {tabel }} \\
(\alpha=0,01 \\
\mathrm{dk}=142)\end{array}$ & $\begin{array}{l}\mathrm{t}_{\text {tabel }} \\
(\alpha=0,05 \\
\mathrm{dk}=142)\end{array}$ & Decision \\
\hline$\rho_{\mathrm{Y} .1}$ & 0,264 & 2,324 & 0,011 & 2,611 & 1.977 & There is a positive direct influence \\
\hline$\rho_{\mathrm{Y} .2}$ & 0,416 & 3,477 & 0,000 & 2,611 & 1.977 & There is a positive direct influence \\
\hline
\end{tabular}

\section{DISCUSSION}

The calculation result of path analysis obtained by path coefficient value $(\rho Y .1)$ equal to 0,264 ( $\rho$ Y.1 $>0)$ with tcount 2,324 , while ttable $(0,05: 142)=1.977$ and ttable $(0,01: 142)=2,611$, so the value is tcount> ttable. This means that it can be concluded that the transformational leadership variable (X1) has a direct positive effect on employee performance (Y). The result of hypothesis testing proves that empirically transformational leadership has a direct positive effect on the performance of administrative staff.

Work programs can be implemented if the support of administrative staff as the core executor of the work program requires leaders who can realize the vision into action. Lunenburg and Ornstein (2011: 30) are aligned as outlined below: Goals are another key element in how transformational leadership works. The above opinion explains that transformational leadership is a key element of goal attainment. This means that transformational leadership can encourage its followers to understand and believe, that by achieving the goals of the organization it will meet their own needs.

Several relevant studies were conducted by Sudarjat, Abdullah and Sunaryo under the title Supervision, Leadership, and Working Motivation to Teachers' Performance. The above research aims to determine the effect of supervision, leadership and motivation on the performance of teachers conducted in junior high school in Bogor, West Java. Test results with a degree of confidence of 0.05 to 289 people found that there is a positive relationship between supervision, leadership, and motivation with performance.

The result of this research concludes that the high performance of administrative staff is caused by the influence of the leadership. In schools with high employee performance, generally having leaders have high expectations for success and focus on achieving academic goals and leadership can influence followers to show their best performance in order to achieve the vision, mission and objectives of the organization as a whole, this is due to exemplary and motivation and insfirmation of transformational leadership that will spur employees to work more effectively and responsibly and the increased discipline of employees. Thus the findings of this study support the view that transformational leadership affects performance.

The results of this study conclude that the high-low performance of administrative staff caused by the influence of leadership. In schools with high employee performance, generally having leaders have high expectations for success and focus on achieving academic goals and leadership can influence followers to show their best performance in order to achieve the vision, mission and objectives of the organization as a whole, this is due to exemplary and motivation and insfirmation of transformational leadership that will spur employees to work more effectively and responsibly and the increased discipline of employees. Thus the findings of this study support the view that transformational leadership affects performance.

Based on the calculation of path analysis, the value of path coefficient $(\rho Y .2)$ is $0,416(\rho Y .2>0)$ with tcount of 3,477 , while ttable $(0,05: 142)=1.977$ and ttable $(0,01: 142)=2.611$, so the value is tcount $>$ 
ttable. This results in empirical findings that personality variables (X2) have a direct positive effect on employee performance (Y).

Based on the results of the analysis can be concluded that there is a direct positive influence of personality on the performance of administrative personnel. If a genuine personality can work together in teams and work responsibilities lead to improved performance of administrative personnel. The results of this supportive study, among others, are presented in several studies, among which are Barrick \& Mount states that "the relationship between personality and job performance has been a frequently studied topic in industrial psychology in the past century." There is a close relationship between personality and performance of the administrative clerk.Effective administrative personnel according to the organization, will be reflected from how the administrative officer concerned performs his or her work in earnest, careful and always wants to be the best in all of his work.

The results showed that the indicator of personality related to performance, responsibility is the best predictor of the performanceThe dimension of personality sincerity and cooperation predict the performance in the form of responsibility and efficiency. Influences between personality and performance dimensions are found, and the results can be used for recruitment, selection and career administration purposes.

\section{CONCLUSION}

Based on the results of data analysis that has been described from the results of this study can be summarized as follows: 1 . There is a direct positive influence of transformational leadership on performance. That is, transformational leadership of a strong direct superior can lead to improved performance of administrative personnel, 2. There is a direct positive influence of personality on the performance of administrative personnel. That is, the appropriate personality can lead to improved performance of administrative staff, 3.Terapat positive influence of achievement motivation on the performance administration administration. Artinyamotivasi high achievers can lead to improved performance of administrative clerks. Personality has a positive direct effect on performance. The implication is that to improve the performance of administrative staff of Universitas PGRI Palembang, the leadership (direct superior) can help generate the seriousness of the administrative staff in working and taking care of the employees by approaching the humane and the harmony of the direct superior as the leader and the employee as subordinate, besides the direct leadership can also play controlling the anxiety of administrative employees in the face of problems while performing their duties. Leaders or direct supervisors should prioritize openness between the leadership and subordinates, and open opportunities employees can openly expressed problems faced in carrying out its duties.

\section{REFRENCES}

Colquitt, Jason.A., Jeffer A. Lepine, \& Michael Wesson. (2013). Organization Behavior Improving Performance and Commitment in Workplace 4 Edition. New York: McGraw-Hill.

Gibson, James L., et al. (2012). Organizations Behavior, Structure, Process. New York: McGraw-Hill.

H.D. Fard, Rajabzedah A. \& Hasin G.A. (2010). "Employees Morales in Public Sector is Organinazational Rust an Important Factor?" European Journal of Scientific Research, Vol. 46 (3).

Jaja Sudarjat, Thamrin Abdullah dan Widodo Sunaryo. (2015). "Supervision, Leadership, and Working Motivation to Teachers Performance," International Journal of Managerial Studies and Research (IJMSR), Vol. 3 (6).

Leslie W. Rue, dan Lloyd L Byars. (2008). Human Resource Management. New York: McGraw-Hill Companies, Inc.

M.R, Barrick \& M.K,Mount. (1996). "Effects Of Impression Management And Self- Boeption On The Predictive Validity Of Personality Constructs, ”Journal of Applied Psychology, Vol. 81.

Rivai, Veithzal. (2005). Kepemimpinan dan Prilaku Organisasi. Jakarta: Raja Grafindo Persada.

Yulk, Gary A. (2013). Leadership in Organization 8 edition. New England: Pearson. 